\title{
Zaman ve Kronolojiyi Algılama Becerisini Nasıl Geliştirebilirim?*
}

\author{
Nurcan Varlıkgörücüsǘ ${ }^{1}$ (iD) Muhittin Çalışkan² \\ Öğretmen, Şehit Ersin Yıldırım Ortaokulu, Şahinbey, Gaziantep, Türkiy \\ nurcan.varlikgorucusu@gmail.com (Sorumlu Yazar/Corresponding Author) \\ Necmettin Erbakan Üniversitesi, Ahmet Keleşoğlu Eğitim Fakültesi, Eğitim Bilimleri Bölümü, Konya, Türkiye \\ mcaliskan@erbakan.edu.tr
}

\begin{tabular}{|c|c|}
\hline Makale Bilgileri & ÖZ \\
\hline $\begin{array}{l}\text { Anahtar Kelimeler: } \\
\text { Eylem araştırması, } \\
\text { Zaman ve kronolojiyi } \\
\text { algılama becerisi, } \\
\text { Sosyal bilgiler öğretimi }\end{array}$ & 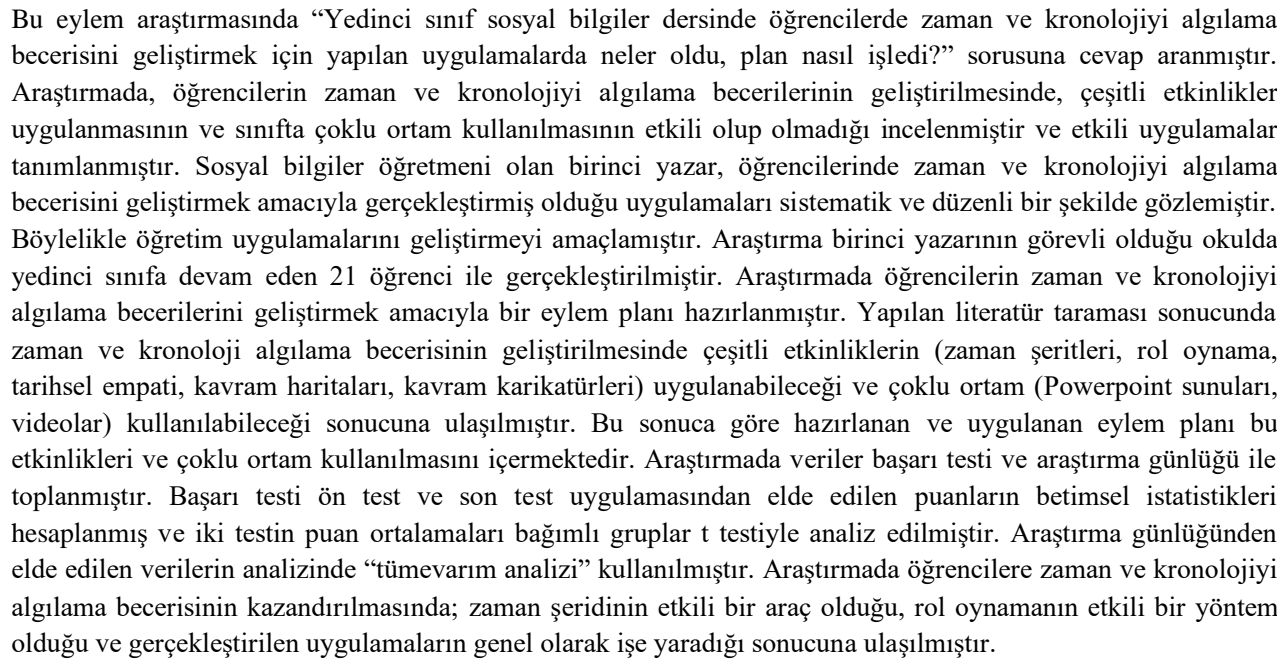 \\
\hline
\end{tabular}

\section{How Can I Improve The Ability To Perceive Time And Chronology?}

\begin{tabular}{|c|c|}
\hline Article Info & ABSTRACT \\
\hline Article History & $\begin{array}{l}\text { This action research sought answer to the question "What happened in the practices in order to improve the } \\
\text { students' perceptions of time and chronology in the seventh grade social studies course, how did the plan work?" }\end{array}$ \\
\hline $\begin{array}{l}\text { Received: } 26.12 .2020 \\
\text { Accepted: } 22.12 .2020 \\
\text { Published: } 28.12 .2020\end{array}$ & $\begin{array}{l}\text { The research examined whether the practice of various activities and the use of multimedia in the classroom were } \\
\text { effective in the development of students' perception of time and chronology and their effective practices were } \\
\text { defined. Being a social studies teacher, the researcher systematically and regularly observed practices to improve } \\
\text { students' ability to perceive time and chronology. The researcher aimed to develop teaching practices in this way. }\end{array}$ \\
\hline Keywords: & The research was carried out with 21 students in the seventh grade in the school where the researcher is teaching. \\
\hline $\begin{array}{l}\text { Action research, } \\
\text { The ability to perceive } \\
\text { time and chronology, } \\
\text { Teaching social studies }\end{array}$ & $\begin{array}{l}\text { An action plan was prepared in order to improve students' perception of time and chronology. The data were } \\
\text { collected through the achievement test and research diary. Descriptive statistics of the scores obtained from the } \\
\text { pre- and post- achievement tests were calculated, and the mean scores of the two tests were analysed by } \\
\text { dependent groups t-test. "Inductive analysis" was used to analyse the data obtained from the research diary. In } \\
\text { equipping the students with the ability to perceive time and chronology it was concluded that the timeline is an } \\
\text { effective tool, role-playing is an effective method and the practices work in general terms. }\end{array}$ \\
\hline
\end{tabular}

Atıf/Citation: Varlıkgörücüsü, N. ve Çalışkan, M. (2020). Zaman ve Kronolojiyi Algılama Becerisini Nasıl Geliştirebilirim, Ahmet Keleşoğlu Eğitim Fakültesi Dergisi, 2(2), 194-209.

\footnotetext{
* Bu çalışma 1. yazarın “Zaman ve Kronolojiyi Algılama Becerisini Nasıl Geliştirebilirim?” başlıklı yüksek lisans tezinden üretilmiştir.
} 


\section{GİRIŞ}

Sosyal bilgiler dersi, sosyal bilimlerin çocuklar tarafından anlaşılabilmesi için sosyal bilimlerin basitleştirilerek okutulduğu bir ilköğretim dersidir (Kabapınar, 2014). Öztürk’e (2006) göre sosyal bilgiler dersi; bireyin toplumsallaşmasına katkı sağlayan, geçmişini öğrenmesini, şimdiki zamanı anlamlandırmasını ve yarına hazırlanmasını sağlayan disiplinler arası bir derstir. Öğrencilerin yaşadığı toplumu benimseyerek, toplumsal sorunların farkında olmaları, iyi ve duyarlı bir vatandaş olmaları, ulusal ve evrensel değerleri içselleştirmelerini sağlayan en temel derslerden biri sosyal bilgiler dersidir. Bireyin kişiliğinin gelişmesinde, topluma uyumlu ve üretken bireyler yetişmesinde sosyal bilgiler dersi önemli bir yere sahiptir (Aykaç, 2007). Sosyal bilgiler dersi genel olarak bireylerin kendisini, yakın ve uzak çevresini tanımasını sağlamayı amaçlayarak bilgi, beceri ve değerler etrafında bütünleşen bir derstir (Dündar, 2008).

Bireyin, sosyal bilgiler dersinin amaçlarına ulaşabilmesi için sosyal bilgiler dersinde yer alan becerileri kazanmış olması gerekmektedir. Sosyal bilgiler dersinde kazandırılması gereken birçok beceri vardır. Bu becerilerden biri de zaman ve kronolojiyi algılama becerisidir (Milli Eğitim Bakanlığı, [MEB], 2005).

Zaman ve kronolojiyi algılama becerisi; takvim bilgisi edinme, zamanları ayırt etme (geçmişşimdiki-gelecek zaman), zaman ifadelerini doğru kullanma, kronolojik sıralama yapma, zaman şeridindeki veriyi yorumlama ve zaman şeridi oluşturma alt becerilerini kapsayan ve bu becerilerin kazanılması durumunda oluşan sosyal bilgiler dersine özgü bir beceridir (Milli Eğitim Bakanlığı, [MEB], 2005). Sosyal Bilgiler dersinin tarih ağırlıklı olan konularının etkili bir şekilde öğretilmesi için öğrencilerin alana özgü beceriler arasında olan zaman ve kronolojiyi algılama becerisini kazanmış olmaları gerekmektedir (Demircioğlu ve Akengin, 2012). Bu becerinin öğrencide temellendirilmemesi durumunda tarih bilinci eksik verilmiş veya hiç verilmemiş olacaktır. Geçmişte yaşanan olay ve olguların tarih verilmeden belirtilmesi öğrencilerde birbirinden bağımsız birçok bilgi yığını yaratacağından tarihi bilgilerin kalıcı şekilde ve anlamlı öğrenilmesi zorlaşacaktır. Bu nedenle geçmişin bilimsel olarak incelenmesi olan tarihin, ilköğretim düzeyinde sağlıklı bir şekilde öğretilmesi için zaman ve kronoloji becerisinin kazandırılmasına önem verilmelidir (Hayden, Arthur ve Hunt, 1997'den akt., Demircioğlu, 2005).

Alanyazın incelendiğinde, zaman ve kronolojiyi algılama becerisi üzerine birçok çalışmanın yapıldığı görülmektedir. Alanyazında; zaman ve kronolojiyi algılama becerisinin nasıl kazandırılabileceğine (Akbaba, Keçe ve Erdem, 2012; Çiviler, 2019; Erdem, 2017; Güngör Akınc1 ve Dilek, 2012; Kekeç, 2018; Şimşek, 2007; Üztemur, 2017; Üztemur, Dinç ve Acun, 2018), öğrencilerin zaman ve kronolojiyi algılama beceri düzeylerine (Çelikkaya ve Kürümlüoğlu, 2019; Demircioğlu, 2005; Filoğlu, 2018; Safran ve Şimşek, 2006), zaman ve kronolojiyi algılama becerisinin öğrenciler tarafindan nasıl algılandığına (Ablak, 2017), öğretmenlerin beceri hakkında ne kadar bilgi sahibi olduklarına ve hangi etkinliklerle kazandırmaya çalıştıklarına (Mutluer, 2013; Sağlam, Tınmaz ve Hayal, 2015), ders kitaplarında bu beceriye ne düzeyde yer verildiğine (Aydemir, 2015; Çelikkaya ve Kürümlüoğlu, 2017); zaman ve kronolojiyi algılama becerisine ne düzeyde önem verildiğine (Çelikkaya, Yıldırım ve Kürümlüoğlu, 2019; Kıbıcı, 2019), öğretmenlerin, öğrencilerine zaman ve kronolojiyi algılama becerisini kazandırma düzeylerine ilişkin görüşlerine (Çelikkaya, 2011; Taşkıran, Baş ve Bulut, 2016) yönelik çalışmalar yapıldığı görülmektedir. Yapılan çalışmalar incelendiğinde zaman ve kronolojiyi algılama becerisinin öğrencilerde yeterince geliştirilemediği, geliştirilmesi için ders kitabı dışında çeşitli materyallerden ve etkinliklerden yararlanılması gerektiği sonucuna ulaşılmaktadır.

Akbaba ve diğerleri (2012), ilköğretim 7. sınıf sosyal bilgiler dersi öğrenme öğretme sürecinde çoklu ortam kullanımının öğrencilerin zaman-kronoloji ile değişim- sürekliliğ̣i algılama becerilerini 
kazanmalarına ve derse yönelik tutumlarına etkisini belirlemeye çalışmışlardır. Çalışma 27 öğrenci ile gerçekleştirilmiştir. Uygulama beş hafta sürmüştür. Öğrencilerin zaman ve kronolojiyi algılama ile değişim ve sürekliliği algılama becerilerinin kazanım düzeylerinin belirlenmesi için ön test ve son test performansları incelendiğinde öğrencilerin deneysel süreç öncesinde söz konusu becerilere sahip olma noktasında önemli eksiklerinin olduğu gözlenmiştir. Deneysel süreç sonrasında ise öğrenci performansları olumlu yönde büyük bir değişim göstermiştir. Çiviler (2019), çalışmasında, 7. sınıf Sosyal Bilgiler dersinde öğrencilerin tarihsel olgu ve yorumları ayırt etme, zaman ve kronolojiyi algılama, tarihsel empati, kalıp yargıları fark etme becerilerini çeşitli etkinlikler uyguladığı eylem araştırması ile geliştirmeyi amaçlamıştır. Çalışma başında öğrencilerin tarihsel düşünme becerilerinin ve tarihsel kavramları algılama düzeylerinin düşük olduğu ve öğrencilerin tarih konularını ezbere dayalı çalıştıkları belirlenmiş̧tir. Öğrencilere uygulama süreci içerisinde tarihçi gibi tarih çalışma imkânı sağlanmış, bunun sonucunda öğrencilerin tarihsel düşünme becerilerinin geliştiği ve öğrencilerin tarihçinin geçmişe bakış açısını kazanmaya başladıkları tespit edilmiştir. Erdem (2017), altıncı ve yedinci sınıf sosyal bilgiler programında bulunan alana özgü becerilerin, etkinlikler yoluyla kazandırılması sürecini ele alan karma yöntem bir araştırma yapmıştır. Araştırmada sosyal bilgiler dersinde beceri temelli etkinlikler yoluyla ders işlemenin etkili olduğu sonucuna ulaşılmıştır. Güngör Akıncı ve Dilek (2012), temsili resim kullanımının öğrencilerin derse ilgi ve yaratıcı, tarihsel düşünme becerileri üzerindeki etkisini belirlemek amacıyla bir araştırma gerçekleştirmişlerdir. Araştırma bulguları, temsilî resimler kullanmanın tarihsel düşünme becerilerini geliştirilebileceğini göstermiştir. Kekeç (2018), ortaokul 7. sinıf öğrencilerine zaman ve kronoloji becerisinin kazandırılmasında, modelleme sürecinin etkili olup olmadığını ortaya koymayı amaçlamıştır. Araştırmada zaman ve kronolojiyi algılama becerisinin kazandırılmasında modelleme sürecinin etkili olduğu sonucuna ulaşılmıştır. Şimşek (2007) çalışmasında, 5. sınıf öğrencilerinin tarihsel zaman kavramı ve kronoloji düşüncelerinin geliştirilmesinde kullanılan birçok öğretim yöntem ve materyaline (zaman çizelgeleri, geçmişe ilişkin fotoğraflar, eski ev aletleri, koleksiyonlar vs.) öğrencilerin ilgileri, tepkileri ile bu öğretim yöntem ve materyallerinin çocukların konuya ilişkin akademik başarılarına katkılarını ele almıştır. Bu araştırma sonucunda çocuklarda tarihsel zaman kavramının uygun yöntem ve yaklaşımlarla çok erken yaşlardan itibaren öğretilebileceğini savunan konu merkezli düşünen araştırmacıların iddialarında olduğu gibi tarihsel zaman araçlarının etkili bir strateji ile kullanılması konunun çocuk tarafından kavranmasında etkili olduğu sonucuna ulaşılmıştır. Üztemur ve diğerleri (2018), ilköğretim 7. sınıf sosyal bilgiler öğretimi bağlamında müzeler ve tarihi mekânlardan etkili yararlanmaya yönelik öğretim etkinlikleri tasarlayarak bu etkinlikleri uygulamak ve bu etkinliklerin öğretme-öğrenme süreçlerinin verimliliğini artırmada ne derece faydalı olduğunu belirlemek amacıyla çalışma yapmıştır. Geliştirilen etkinlikler aracılığıyla öğrencilerde gözlem, değişim ve sürekliliği algılama, sosyal katılım, tarihsel empati, mekânı algılama ve zaman ve kronolojiyi algılama becerilerinin geliştiği görülmüştür.

Alanyazındaki zaman ve kronoloji becerisini konu alan araştırmalar incelendiğinde, çeşitli etkinliklerden yararlanmanın ve çoklu ortam uygulamalarının zaman ve kronolojiyi algılama becerisinin geliştirilmesinde etkili olabileceği sonucuna ulaşılmıştır. Sosyal bilgiler öğretmeni olan birinci yazar öğrencilerinin zaman ve kronoloji becerilerini geliştirmek için çeşitli etkinliklerden ve çoklu ortam uygulamalarından faydalanmayı planlamıştır. Bu amaçla bir eylem planı hazırlamıştır. Eylem planını hazırlamadan önce zaman ve kronolojiyi algılama becerisinin ne olduğu ve nasıl geliştirilebileceği, eylem araştırmasının nasıl yapılması gerektiğiyle ilgili çalışmaları incelemiştir. Bu çalışmada, hazırlanan eylem planının uygulaması sürecinde neler olduğuna ve bu uygulamanın yazarın öğretim uygulamalarına katkısına odaklanılmıştır.

$\mathrm{Bu}$ çalışmanın temel amac1; öğrencilerin zaman ve kronolojiyi algılama becerilerinin geliştirilmesinde, çeşitli etkinlikler uygulanmasının ve sınıfta çoklu ortam kullanılmasının etkili olup 
olmadığını incelemek ve etkili uygulamaları tanımlamaktır. Bu temel amaç doğrultusunda araştırmada "Yedinci sınıf sosyal bilgiler dersinde öğrencilerde zaman ve kronolojiyi algılama becerisini geliştirmek için yapılan uygulamalarda neler oldu, plan nasıl işledi?” sorusuna cevap aranmıştır.

\section{YÖNTEM}

\section{Araştırma Modeli}

Araştırmanın sorusunu cevaplamak amacıyla bir eylem araştırması gerçekleştirilmiştir. Eylem araştırmaları, öğretmenlerin kendi uygulamalarını gözlemlemek, incelemek için sistematik ve düzenli bir yoldur. Amaç, öğretmenin öğretim uygulamalarını geliştirmektir (Johnson, 2015). Bu araştırmada da sosyal bilgiler öğretmeni olan birinci yazar, öğrencilerinde zaman ve kronolojiyi algılama becerisini geliştirmek amacıyla gerçekleştirmiş olduğu uygulamaları sistematik ve düzenli bir şekilde gözlemiştir. Böylelikle öğretim uygulamalarını geliştirmeyi amaçlamıştır.

\section{Çalışma Grubu}

Araştırmanın çalışma grubu sosyal bilgiler öğretmeni olan birinci yazarın derslerine girdiği yedinci sınıflar arasındaki şubelerden birindeki öğrencilerdir. Sınıfta 21 öğrenci (10 erkek, 11 kız) vardır. Ailelerin sosyo-ekonomik düzeyi düşüktür ve yaşadıkları şehre göç etmişlerdir. Öğrencilerin kendilerine ait odaları yoktur. Öğrencilerin derse ilgileri, tutumları ve akademik başarıları düşüktür. Öğrencilerin bir kısmı çocuk işçidir, bir yerde çalışmaktadır. Sınıfta hafif düzeyde zihinsel yetersizliği olan ve bireyselleştirilmiş eğitim programı uygulanan iki öğrenci vardır.

\section{İşlem Basamakları}

Altı hafta süren araştırmada aşağıdaki işlemler gerçekleştirilmiştir:

1.Uygulamanın ilk haftasında ve son haftasında başarı testinin ön test ve son test uygulamaları yapılmıştır. Öğretim etkinlikleri ise 4 hafta (12 ders saati) sürmüştür. Tüm süreç boyunca araştırmacı araştırma günlügünü tutmuştur.

2.Bu çalışmada öğrencilerin zaman ve kronolojiyi algılama becerilerini geliştirmek amacıyla bir eylem planı hazırlanmıştır. Yapılan literatür taraması sonucunda zaman ve kronoloji becerisinin geliştirilmesinde çeşitli etkinliklerin (zaman şeritleri, rol oynama, tarihsel empati, kavram haritaları, kavram karikatürleri) uygulanabileceği ve çoklu ortam (PowerPoint sunuları, videolar) kullanılabileceği sonucuna ulaşılmıştır. $\mathrm{Bu}$ sonuca göre hazırlanan eylem planı bu etkinlikleri ve çoklu ortam kullanılmasını içermektedir. Uygulama "zaman içinde bilim” ünitesinde gerçekleştirilmiştir.

3.Öğretmen tarafından zaman şeritleri hazırlanmıştır. Hazırlanan bu zaman şeritleri öğrencilerle birlikte yorumlanmıştır. Öğrencilerin zaman ve kronolojiyi algılama becerilerini geliştirmek ve onların gelişimini gözlemek amacıyla öğrencilere de zaman şeritleri çizdirilmiştir.

4.Eğitim Bilişim Ağından (EBA) sıklıkla yararlanılmıştır.

5.Tarihsel empatiye dayalı rol oynama yöntemi uygulanmıştır. Öğrencilere çeşitli bilim insanlarının yaşadıkları zamanla empati kurabilecekleri şekilde rol kartları dağıtılarak bu yöntem uygulanmıştır.

6.Kavram haritaları ve kavram karikatürleri sunulmuştur.

7.Sanal müze ziyaretleri yapılmıştır.

8.Dersin işlenmesinde eğitim bilişim ağındaki videolardan ve PowerPoint sunularından faydalanılmıştır. Zaman şeritlerinin, kavram karikatürlerinin, kavram haritalarının, resimlerin gösterimi PowerPoint sunuları ile gerçekleştirilmiştir.

\section{Veri Toplama Araçları}

Araştırmada veriler başarı testi ve araştırma günlüğü ile toplanmıştır. Başarı testi Kekeç (2018) tarafından geliştirilmiştir. Test, zaman ve kronoloji becerisinin kazandırılmasında modelleme 
etkinliklerinin etkililiğini sınamak amacıyla öğrencilerin zaman içinde bilim ünitesindeki başarılarını ölçmek için geliştirilmiştir. Bu çalışmada da hem amacın aynı olması hem de etkinliklerin aynı ünitede gerçekleştirilmiş olması bu başarı testinin kullanılma gerekçesi olmuştur. Testte 30 madde vardır. Kekeç (2018), testin KR-20 güvenirlik katsayısını 0,863 olarak hesaplamıştır.

Araştırma günlüğü araştırmanın tüm bölümleriyle ilişkili gözlemleri ve düşünceleri kayıt etmek için kullanılan bir defterdir. Araştırma günlügünde süreçle ilgili gözlemler, analizler, şekiller, taslaklar, alıntılar, öğrenci yorumları, sınav sonuçları, düşünceler, duygular ve izlenimler gibi çok çeşitli verilere yer verilebilir (Johnson, 2015, s. 81). Araştırmada süreçle ilgili gözlemler, duygular, düşünceler ve öğrenci yorumları araştırma günlüğüne kaydedilmiştir.

\section{Verilerin Toplanması}

Başarı testi uygulamanın başında (Şubat 2020) ve sonunda (Mart 2020) iki kez uygulanmıştır. Araştırma günlüğü dersten sonra ya da günün sonunda yazılmıştır. Öğretmen süreçle ilgili gözlemlerini, duygularını, düşüncelerini ve öğrenci yorumlarını araştırma günlüğüne yazmıştır. Otuz altı sayfa bir günlük elde edilmiştir.

\section{Verilerin Analizi}

Başarı testi ön test ve son test uygulamasından elde edilen puanların betimsel istatistikleri hesaplanmış ve iki testin puan ortalamaları bağımlı gruplar $\mathrm{t}$ testiyle analiz edilmiştir. Araştırma günlüğünden elde edilen verilerin analizinde "tümevarım analizi" kullanılmıştır. Tümevarım analizi, bir alana veya bir grup veriye bakmak ve gruplar içinde gözlemleneni düzenleyerek tüme varmaya ya da bir düzen oluşturmaya gayret etmek anlamına gelir (Johnson, 2015, s. 112). Araştırma günlügüne yazılanlar incelenmiş, yinelenen öğeler, temalar aranmıştır. Benzer şeyler kodlanmıştır ve kategorilere taşınmıştır. Bunu yapabilmek için öncelikle neyin arandığına dair bir ölçüt oluşturması için bir soru belirlenmiştir. Bu soru şudur: "Günlükte öğrencilerin zaman ve kronolojiyi algılama becerisinin geliştiğini gösteren ifadeler nelerdir?" Bu soru ışığında başlangıç kategorileri belirlenmiştir. Yinelenen analizlerde bu kategoriler netleşmiştir ve netleşen kategorilere göre de alt kategoriler oluşturulmuştur.

\section{BULGULAR}

Bu araştırmada, "Yedinci sınıf sosyal bilgiler dersinde öğrencilerde zaman ve kronolojiyi algılama becerisini geliştirmek için yapılan uygulamalarda neler oldu, plan nasıl işledi?” sorusuna cevap aranmıştır. Öğrencilerin uygulama öncesindeki ve uygulama sonrasındaki zaman ve kronolojiyi algılama becerilerindeki durumu betimlemek amacıyla başarı testinden alınan ön test ve son test puan ortalamaları bağımlı gruplar $t$ testi ile analiz edilmiştir. Ön test ve son test puanlarının normalden aşırı sapmadığı görülmüştür. Ön test ve son test puanlarının çarpıklık ve basıklık katsayıları -,956 ile 1,374 arasında değişmektedir. Analiz sonuçları Tablo 1'de gösterilmiştir.

Tablo 1. Başarı Testi Ön test ve Son test Ortalama Puanlarının t- Testi Sonuçları

\begin{tabular}{cccccc}
\hline Ölçüm & $\mathbf{N}$ & $\overline{\mathbf{X}}$ & ss & sd & $\mathbf{T}$ \\
Ön test & 21 & 9,48 & 3,09 & 20 & $-3,069^{*}$ \\
Son test & 21 & 13,38 & 6,48 & & \\
\hline
\end{tabular}

$* \mathrm{p}<0,05$

Tablo 1'de görüldüğü gibi ön test puan ortalamas1 9,48 ve son test puan ortalamas1 13,38'dir. Ortalamalar arasında son test lehine anlamlı bir fark vardır $[\mathrm{t}(20)=-3,069, \mathrm{p}<0,05)$. Buna göre, uygulamanın, son test puanlarında ön test puanlarına göre fark yarattığı söylenebilir. Bir başka deyişle 
çeşitli etkinlikler uygulanmasının ve sınıfta çoklu ortam kullanılmasının öğrencilerin zaman ve kronolojiyi algılama becerilerinin gelişmesinde etkili olduğu söylenebilir.

Yedinci sınıf sosyal bilgiler dersinde öğrencilerde zaman ve kronolojiyi algılama becerisini geliştirmek için yapılan uygulamalarda neler olduğunu, planın nasıl işlediğini betimlemek için araştırma günlüğü tümevarım analizi ile analiz edilmiştir. Analiz sonucunda; "materyalin etkililiğine ilişkin karalar", "zaman şeridi”, "kavram karikatürü”, "video", "sanal müze ziyaretleri”, "rol oynama”, düz anlatım", "soru-cevap", "gösterip yaptırma", "öğrencilerin başlangıçtaki durumları" ve "süreçteki gözlemler" olmak üzere 11 kategoriye ulaşılmıştır. Bu kategorilere ilişkin alt kategorilerin araştırma günlüğündeki yinelenme sayısı verilmiştir. Analiz sonuçları Tablo 2'de verilmiştir.

Tablo 2. Araştırma Günlügünün Analizi

\begin{tabular}{|c|c|}
\hline Kategoriler ve alt kategoriler & $\mathbf{F}$ \\
\hline Materyalin etkililiğine ilişsin kararlar & 6 \\
\hline Daha çok zaman şeridi örneği gösterme & 1 \\
\hline Daha çok zaman şeridi çizdirme & 1 \\
\hline Videolar etkili oluyor & 1 \\
\hline Ilk önce basit olan çizgisel, metrik ve hat olan zaman şeritleri tercih edilmeli & 1 \\
\hline Öğrencilerin ilgilerini ve dikkatini çekmediğinden sanal müze ziyaretlerinden vazgeçme & 1 \\
\hline Senkronik zaman şeridi kullanmanın etkili olmadığ1 & 1 \\
\hline Zaman şeridi & $\begin{array}{l}1 \\
3\end{array}$ \\
\hline Öğretmenin eğitim öğretim hayatını gösteren zaman şeridini sunma & 1 \\
\hline Insanlık tarihinin çağlara ayrılmasını gösteren zaman şeridini sunma & 1 \\
\hline 15. yüzyıldan günümüze bilginin korunmasında etkili olan icatları gösteren zaman şeridini sunma & 1 \\
\hline Gösterilen zaman şeritlerini öğrencilerin defterlerine çizmeleri & 1 \\
\hline Zaman şeritlerini akıllı tahtada gösterme & 1 \\
\hline Öğrencilerden kendi eğitim-öğretim hayatlarını anlatan bir zaman şeridi çizmelerini isteme & 1 \\
\hline Öğrencilerden yaşadıkları önemli olayları gösteren zaman şeridi çizmelerini isteme & 1 \\
\hline Yazının gelişimi ve bilgiyi saklamada kullanılan araçları gösteren zaman şeridini sunma & 1 \\
\hline İnsanlık tarihinin çağlara ayrılmasını gösteren zaman şeridini tekrar sunma & 1 \\
\hline Türk-İslam bilginlerini gösteren zaman şeridini sunma & 1 \\
\hline 15. ve 20. yüzyıllar arasında Avrupa'da yaşanan bilimsel gelişmeleri gösteren zaman şeridini sunma & 1 \\
\hline Öğrencilerden kendi eğitim-öğretim hayatlarını anlatan bir zaman şeridi çizmelerini tekrar isteme & 1 \\
\hline $\begin{array}{l}\text { Öğrencilerden canlandırdıkları bilim insanlarının yaptıkları çalışmaları zaman şeridinde } \\
\text { göstermelerini isteme }\end{array}$ & 1 \\
\hline Kavram karikatürü & 1 \\
\hline $\begin{array}{l}\text { Zaman ve kronoloji arasındaki ilişkiyi anlayabilmeleri için kendi hazırladığım kısa bir kavram } \\
\text { karikatürünü sundum }\end{array}$ & 1 \\
\hline Video & 5 \\
\hline Eğitim Bilişim Ağından (EBA) konu ile ilgili videolar izletme & 4 \\
\hline EBA dışındaki kaynaklardan video izletme & 1 \\
\hline Sanal müze ziyaretleri & 3 \\
\hline
\end{tabular}




\begin{tabular}{|c|c|}
\hline Konu ile ilgili sanal müzeleri ziyaret etme & 3 \\
\hline Rol oynama & 2 \\
\hline & 1 \\
\hline Her bir öğrencinin farklı bir bilim insanını canlandırması & 2 \\
\hline & 1 \\
\hline Düzanlatım & 9 \\
\hline Zaman ve kronoloji kavramı & 2 \\
\hline Kavramlar (çağ, zaman, yüzyıl, milattan önce, milattan sonra) & 2 \\
\hline Türk-İslam bilginleri & 1 \\
\hline Zamanla her şeyin değişebileceğine örnekler verme & 1 \\
\hline Takvim bilgisi (takvim türleri, özellikleri) & 1 \\
\hline Güneş y1l1, ay y1lı & 1 \\
\hline Matbaanın icadı ve önemi & 1 \\
\hline Çeyrek & 1 \\
\hline Türkler'in kullandıkları takvimler & 1 \\
\hline Soru-cevap & 2 \\
\hline Soru-cevap & 1 \\
\hline Gösterip yaptırma & 2 \\
\hline Zaman şeridinin nasıl çizildiği & 1 \\
\hline Yılların yüzyıla nasıl çevrildiği & 1 \\
\hline Öğrencilerin başlangıçtaki durumları & 8 \\
\hline Zaman şeridinin ne olduğunu bilmiyorlar & 2 \\
\hline Yüzyıl kavramını bilmiyorlar & 1 \\
\hline Zaman şeridine isim vermemişler & 1 \\
\hline Zaman şeridinde zamansal sıralamayı yapamıyorlar & 1 \\
\hline Milattan önce-milattan sonra ve tarih öncesi-tarihi çağları karıştırma & 1 \\
\hline Takvim bilgileri eksik & 1 \\
\hline $\begin{array}{l}\text { Genel bilişsel giriş davranışlarında (okuma, okuduğunu anlama, neden-sonuç ilişkisi kurma vb.) } \\
\text { eksiklikler }\end{array}$ & 1 \\
\hline Sürecteki gözlemler & 5 \\
\hline & 3 \\
\hline Bazı öğrenciler zaman şeritlerine isim verebildiler & 1 \\
\hline Bazı öğrenciler zamansal sıralamayı doğru yapabildiler & 1 \\
\hline Zaman şeridini kavradılar & 1 \\
\hline Zaman şeridi üzerinden sorulan sorulara doğru cevaplar verebildiler & 1 \\
\hline Zaman şeridi oluşturmada güçlük yaşayan öğrenciler var & 1 \\
\hline Çağları ayırt etmede yaşanan güçlük devam ediyor & 1 \\
\hline Zamanla her şeyin değişebileceği anlaşıldı & 1 \\
\hline Bazı öğrenciler ilkçağda yer alan yıllar ile ortaçağda yer alan yılları karıştırıyor & 1 \\
\hline Sürekliliği algıladılar & 2 \\
\hline Bilimsel çalışmaların ve icatların da kronolojisi olduğu anlaşıldı & 1 \\
\hline
\end{tabular}




\begin{tabular}{ll}
\hline Değişimi algıladılar & 3 \\
\hline Zaman şeridindeki veriyi yorumlamada oldukça geliştiler & 1 \\
\hline Yakınlık-uzaklık algıları gelişti & 1 \\
\hline Çağ kavramı anlaşıldı & 2 \\
\hline Çağ kavramında bazı öğrencilerde sorun var & 1 \\
\hline Milattan önce-milattan sonra kavramlarında istenilen seviyeye yaklaştık sayılır & 2 \\
\hline Bir yılın hangi yüzyılın içinde olduğu sorusuna doğru cevap veriyorlar & 1 \\
\hline Yüzyıl kavramı anlaşıldı & 1 \\
\hline Zaman şeridinde yer alan bilim insanlarından hangilerinin her iki yüzyılda da yaşadığını doğru tespit & 1 \\
edebildiler & 1 \\
\hline Çeyrek kavrandı & 1 \\
\hline Zaman şeridi çizmede ilk derslere göre daha başarılılar & 1 \\
\hline Zaman şeridinde zamansal sıralama ve düzenleme yapamayan birkaç öğrenci var & 1 \\
\hline Ödevler istenilen düzeyde değil & 1 \\
\hline Canlandırdığı bilim insanının kaçıncı yüzyılda ve hangi çağda yaşadığını doğru söyleyebildi & 7 \\
\hline Canlandırdığı bilim insanının kaçıncı yüzyılda yaşadığını doğru söyleyebildi ancak hangi çağda & 3 \\
yaşadığını söyleyemedi & 1 \\
\hline Canlandırdı̆̆ı bilim insanının kaçıncı yüzyılda ve hangi çağda yaşadığını söylerken zorlandı & 1 \\
\hline Canlandırılan bilim insanlarından en yaşlısını doğru olarak belirleyebildiler & 1 \\
\hline Bir öğrenci kaçıncı yüzyılda yaşadığını cevaplayamadı & 1 \\
\hline Dört öğrenci yaşadığı çağı bilemedi & 1 \\
\hline Milattan önce dönemde yer alan yıllardan hangisinin günümüze daha uzak ya da daha yakın olduğu \\
anlaşıldı çünkü en yaşlı bilim insanını doğru söylediler
\end{tabular}

Aşağıda her bir kategori tanımlanmıştır ve açıklanmıştır:

\section{Materyalin etkililiğine ilişsin kararlar}

Bu kategori, öğretmenin, uygulama sürecinde kullandığı materyallerin etkililiğine ilişkin aldığ1 kararlarını içermektedir. Öğretmen uygulama sürecinde bazı kararlar almıştır. Bu kararlar şunlardır: Öğrencilere daha çok zaman şeridi örneği gösterilmelidir ve onlara daha çok zaman şeridi çizdirilmelidir. İlk başlarda basit olan çizgisel, metrik ve hat olan zaman şeritleri kullanılmalıdır. Senkronik zaman şeridi etkili olmamaktadır. Sanal müze ziyaretlerinin öğrencilerin ilgilerini ve dikkatlerini çekmemiştir. Videolar etkili olmuştur. Bu durumda zaman şeritlerinin öğrencilere zaman ve kronolojiyi algılama becerisinin kazandırılmasında etkili bir araç olduğu söylenebilir.

\section{Zaman şeridi}

Bu kategori, öğretmenin öğrencilerinin zaman ve kronolojiyi algılama becerilerini geliştirmek için kullandığı materyallerden biri olan zaman şeridini nasıl kullandığını ve zaman şeridinin içeriklerinin ne olduğunu içermektedir. Tablodan öğretmenin çok farklı konuları içeren zaman şeritleri sunduğu anlaşılmaktadır. Öğrencilere de zaman şeritleri çizdirdiği görülmektedir. Uygulamada zaman ve kronolojiyi algılama becerisinin kazandırılmasında en çok kullanılan materyal zaman şeridi olduğu anlaşılmaktadır.

\section{Kavram karikatürü}


Bu kategori, öğretmenin kullandığı materyallerden biri olan kavram karikatürünü hangi amaçla kullandığını içermektedir. Öğretmen, öğrencilerin zaman ve kronoloji arasındaki ilişkiyi anlayabilmeleri için kendi hazırladığı kısa bir kavram karikatürünü sunmuştur. Ancak kavram karikatürünün süreçte başka kullanılmaması dikkat çekicidir.

\section{Video}

Bu kategori, öğretmenin öğrencilere konu ile ilgili izlettiği videoların kaynaklarını içermektedir. Öğretmen Eğitim Bilişim Ağından (EBA) ve başka kaynaklardan konu ile ilgili videolar izletmiştir.

\section{Sanal müze ziyaretleri}

Bu kategori, öğretmenin öğrencilere konu ile ilgili izlettiği videoların kaynaklarını içermektedir. İki farklı müze sanal ortamda ziyaret edilmiştir.

\section{Rol oynama}

Bu kategori, öğretmenin rol oynama yöntemini nasıl kullandığını içermektedir. Öğrenciler seçmiş oldukları bilim insanını rol oynama yöntemiyle canlandırmışlardır. Her öğrenci bu etkinliği yapmıştır.

\section{Düzanlatım}

$\mathrm{Bu}$ kategori, öğretmenin hangi kavramları açıklamada düzanlatım yöntemini kullandığını içermektedir. Öğretmen bazı kavramları ve konuları açıklamada düzanlatım yöntemi kullanmıştır.

\section{Soru cevap}

$\mathrm{Bu}$ kategori, öğretmenin süreçte doğrudan kavramların anlaşılması amacıyla sorduğu soruları içermektedir. Öğretmen temel kavramların anlaşılıp anlaşılmadığını tespit etmede ve bazı önemli noktalara dikkat çekmede soru-cevap yöntemini kullanmıştır. Örneğin "Canlandırılan bilim insanlarından hangisi günümüze daha yakın bir zamanda yaşamıştır?" ya da "Hangi bilim insanı farklı iki yüzyılda da yaşamıştır?" gibi.

\section{Gösterip yaptırma}

Bu kategori, öğretmenin neyi kazandırma gösterip yaptırma yöntemini kullandığını içermektedir. Öğretmen zaman şeridinin nasıl çizileceğini ve yılların yüzyıla nasıl çevrileceğini göstermede bu yöntemi kullanmıştır.

\section{Öğrencilerin başlangıçtaki durumları}

$\mathrm{Bu}$ kategori uygulamanın başında öğrencilerin sahip oldukları genel ve özel bilişsel giriş davranışlarını (ön öğrenmeleri) içermektedir. Özellikle öğrencilerin genel bilişsel giriş davranışlarındaki eksiklikler dikkat çekmektedir.

\section{Süreçteki gözlemler}

$\mathrm{Bu}$ kategori süreçte öğrencilerde gözlenen durumu içermektedir. Öğrenciler, uygulamanın başındaki durumlarına göre, zaman şeridi çizmede, doğru zamansal sıralama yapmada ve zaman şeridini yorumlamada gelişme göstermişlerdir. Ancak zaman şeridi çizemeyen, zaman şeridinde zamansal sıralama ve düzenleme yapamayan birkaç öğrenci de vardır. Tablodan uygulama sürecinde ve sonunda çağ, yüzyıl, değişim, süreklilik, yakınlık-uzaklık, milattan önce-milattan sonra, çeyrek kavramlarının kavrandığ1 anlaşılmaktadır. Ancak çağları ayırt edemeyen öğrenciler ve yaşadığı çağı bilemeyen öğrenciler de (4 öğrenci) vardır. Yirmi bir öğrenciden on yedisinin "canlandırdığı bilim insanının kaçıncı yüzyılda ve hangi çağda yaşadığını doğru söyleyebilmesi” dikkat çeken bir bulgudur. Bu bulguya 
dayanarak rol oynamanın zaman ve kronolojiyi algılama becerisinin kazandırılmasında etkili bir yöntem olduğu söylenebilir.

Özetle öğrencilere zaman ve kronolojiyi algılama becerisinin kazandırılmasında; zaman şeridinin etkili bir araç olduğu, rol oynamanın etkili bir yöntem olduğu ve gerçekleştirilen uygulamaların genel olarak işe yaradığı söylenebilir.

\section{TARTIŞMA ve SONUÇ}

$\mathrm{Bu}$ çalışmada öğrencilerin zaman ve kronolojiyi algılama becerilerinin geliştirilmesinde, çeşitli etkinlikler uygulanmasının ve sınıfta çoklu ortam kullanılmasının etkili olup olmadığını incelenmiştir ve etkili uygulamalar tanımlanmaya çalışılmıştır. Araştırmada veriler başarı testi ve araştırma günlügü ile toplanmıştır.

Araştırmada özetle şu bulgulara ulaşılmıştır: Ön test puan ortalaması ile son test puan ortalaması arasında son test lehine anlamlı bir fark bulunmuştur. Çeşitli etkinlikler uygulanmasının ve sınıfta çoklu ortam kullanılmasının öğrencilerin zaman ve kronolojiyi algılama becerilerinin gelişmesinde etkili olduğu söylenebilir. Öğretmen uygulama sürecinde bazı kararlar almıştır. Bu kararlar; "Öğrencilere daha çok zaman şeridi örneği gösterilmelidir ve onlara daha çok zaman şeridi çizdirilmelidir.”, "İlk başlarda basit olan çizgisel, metrik ve hat olan zaman şeritleri kullanılmalıdır.", "Senkronik zaman şeridi etkili olmamaktadır.", "Sanal müze ziyaretlerinin öğrencilerin ilgilerini ve dikkatlerini çekmemiştir.", "Videolar etkili olmuştur." Bu durumda zaman şeritlerinin öğrencilere zaman ve kronolojiyi algılama becerisinin kazandırılmasında etkili bir araç olduğu söylenebilir. Zaman şeridi, zaman ve kronolojiyi algılama becerisinin kazandırılmasında en çok kullanılan materyal olmuştur. Öğrenciler, uygulamanın başındaki durumlarına göre, zaman şeridi çizmede, doğru zamansal sıralama yapmada ve zaman şeridini yorumlamada gelişme kat etmişlerdir. Öğrenciler çă̆, yüzyıl, değişim, süreklilik, yakınlık-uzaklık, milattan önce-milattan sonra, çeyrek kavramlarını anlamışlardır. Ancak bazı öğrencilerde bu gelişim sağlanamamıştır. Rol oynamanın zaman ve kronolojiyi algılama becerisinin kazandırılmasında etkili bir yöntem olduğu görülmüştür.

Zaman şeridi çizemeyen, zaman şeridinde zamansal sıralama ve düzenleme yapamayan, çağları ayırt edemeyen ve yaşadığı çağı bilemeyen öğrenciler de vardır. Bu durum öğrencilerin genel bilişsel giriş davranışlarındaki eksiklikler ile açıklanabilir. Genel nitelikteki bilişsel giriş davranışları, her tür öğrenme için gerekli olan giriş nitelikleridir ve okuldaki başarıda en önemli faktör olarak görülmektedir. Ancak, genel nitelikli bilişsel giriş davranışları değişmeye dirençli özelliklerdir (Senemoğlu, 2013, s. 446-447).

Sonuç olarak, öğrencilerin zaman ve kronolojiyi algılama becerilerinin geliştirilmesinde, çeşitli etkinlikler uygulanmasının ve sınıfta çoklu ortam kullanılmasının genel olarak etkili olduğu, zaman şeridinin etkili bir materyal, rol oynamanın etkili bir yöntem olduğu söylenebilir.

\section{ÖNERILER}

$\mathrm{Bu}$ çalışma sonunda getirilebilecek öneriler ve araştırmanın sınırlılıkları hakkında daha ayrıntılı bilgi vereceği düşünüldüğünden aşağıda öğretmenin süreçle ilgili yapmış olduğu yansıtma sunulmuştur.

$\mathrm{Bu}$ araştırmanın öğretim uygulamalarımı geliştirmek adına bana çok şey kattığını düşünüyorum. Zaman ve kronolojiyi algılama becerisinin ne olduğunu ve bu becerinin geliştirilmesinin ne kadar önemli olduğunu gördüm. Geçen yıl da 7. sınıflara girmiştim aynı üniteyi işlemiştim. Bu becerinin öneminin, ne olduğunun ve nasıl kazandırılacağının farkında değildim. Çocukların becerilerini geliştirmek için onları işe katacak bir etkinlik yaptırmamıştım. Mesela zaman şeridi çizdirmemiştim. Artık çizdireceğim. Uygulama öncesinde çocukların bu beceriyle ilgili şimdiye kadar sahip olmaları gereken bilgi ve becerilere sahip olmadıklarını gördüm. Bu beceri tek bir etkinlikle ve kısa bir sürede gerçekleşecek bir 
beceri değil. Bundan sonra her sınıf seviyesinde kazanımlara uygun olarak bu beceriyi geliştirebilmek için etkinlikler yapacağım. Rol oynama yönteminin bu becerinin geliştirilmesinde etkili bir yöntem olduğunu düşüyorum. Bu yöntem hem çocukları işe katıyor, hem eğlenmelerini sağlıyor. Öğrenciler bana en çok bu etkinliği sevdiklerini söylediler. Canlandırma yaptıkları kişiler üzerinden sorular sorularak zaman ve kronoloji becerileri çok rahat geliştirilebiliyor ve ölçülebiliyor. Süreç, beceri geliştirme dişında hem öğretmen hem bir birey olarak bana çok önemli bir şeyi kanıtladı: "Sevmeyen çocuk öğrenemez." Öğretim yapmadan önce ilk adım olarak çocukların beni sevmesine çalışacağım. Çocukların beni sevmelerine çalıştım. Beni sevdiklerini ve bu sevginin becerinin gelişmesinde etkili olduğunu düşüyorum. Öğrencilere yazı yazdırmanın kısıtlı seviyede tutulması gerektiğini teyit ettim. Çünkü yazdırarak vakit boşa harcanıyor. Bunun yerine etkinlik yapılabilir, soru çözdürülebilir. Daha verimli bir öğrenme olacaktır. Ayrıca öğrenciler de yazı yazmaktan pek hoşlanmıyor. Öğretimde ölçmede kullanılabilecek bazı uygulamaları öğrendim. Bundan sonra bir plan hazırladığımda ön test-son test kullanarak ve günlük tutarak yaptığım bir uygulamanın etkililiğini değerlendirebilirim.

$\mathrm{Bu}$ araştırmada şunları fark ettim. Zaman ve kronolojiyi algılama becerisi her seviyedeki öğrencilerde geliştirilebilir. Dersine girdiğim sınıfın akademik başarısı oldukça düşüktü. Hatta çoğu öğretmen "neden bu sınıfta uygulama yaptığımı" sordu ve "çok daha iyi bir sınıfta uygulama yapabileceğimi" söyledi. Çalışmamda istediğim gibi olmayan şeyler olmakla birlikte çalışmamdan memnun olduğum kısımlar da var. Çünkü öğrencilerim zaman ve kronolojiyi algılama becerisiyle ilişkili gelişmeler gösterdiler. Artık milat hesaplaması yapabiliyorlar, zaman içerisinde değişimlerin olabileceğini kavradılar, zamansal olarak yakınlık-uzaklık algısına sahip oldular, zaman şeritlerini yorumlayabiliyorlar. Çağ kavramıyla ilgili olarak bazı eksiklikler olsa da artık bilgi sahibi oldular. Zaman şeridi hakkında da artık yeterince bilgileri var. İlk derslerde bana zaman şeridi ne diye sormuşlardı, ön bilgileri oldukça eksikti.

Öğrencilerimin zaman ve kronolojiyi algılama becerisiyle ilişkili olan bazı kazanımları edinmeleri beni oldukça mutlu etti. Kendimi yeterli hissettim. Ancak öğrencilerimin bazı kazanımları edinememeleri beni üzdü. Bazı kazanımların edinememelerinin iki nedeni olabilir. Birincisi, ders planımda öğrencilerin zorlanabilecekleri çağ kavramı, zaman şeridi çizme gibi bazı kavram ve becerilere yönelik ekonomik bir etkinlik planlayabilirdim. Sınıfta bu kavram ve becerilere olabildiğince yer verdim. Ama öğrenmeleri için yeterli olmadı. İkincisi, üniteye ayrılan süre çok kısaydı. Benim geliştirmem gereken beceri ise çok boyutlu olan 6 alt becerisi bulunan bir beceriydi. Bu kısıtlı sürede kazandırabilecek olduklarıma yoğunlaşmak geri kalanlarda ise en azından bilgi sahibi olmalarını sağlamak istedim. Belki bunu düşünmekte yanlış ettim. Kazanmakta zorlandıkları o bilgi ve becerilere sadece sınıf içerisinde yer verdim. Sınıf dışında ödev vermek gerekiyordu belki de. Bunu yapmamamın nedeni de daha önce verdiğim ödevleri yapmayan öğrencilerin çok olmasıydı. Öğrencilerimin belli bir ön bilgiyle gelmesi gerekiyordu. Yedinci sınıf oldukları için çăg, takvim, zaman şeridi gibi kavramları bilmeleri gerekiyordu, benim de geliştirmem. Ancak öğrencilerimin ön bilgileri çok eksikti. Öğrencilerimin bilgi sahibi olmasını sağlamak anca yetiştirilebilecek bir şeydi.

Bilimsel bir çalışma yapmak amacıyla ilk defa ders işledim. Bu benim için bir ilkti. Derslerimi genelde planlarım ama bu kadar detaylı ve yazıya dökerek değil. İlk defa alanımla ilgili bir beceriyi ve nasıl kazandırılması gerektiğini bu kadar detaylı inceledim ve bilgi edindim. Bu çalışma sayesinde öncelikle bilgi seviyem değişti. Artık zaman ve kronolojiyi algılama becerisinin ne olduğunu ve ne kadar önemli olduğunu detaylıca biliyorum. Bu beceriyi nasıl kazandırmam gerektiğini de öğrendim diyebilirim. En azından çalışma yaptığım sınıfla aynı seviyede olan bir sınıfta bu becerinin nasıl kazandırılması gerektiğini öğrendim. 
Bu çalışmada farklı olarak zaman kapsülü de kullanabilirdim. Öğrencilerin yaptıkları çalışmaları zaman kapsülü şeklinde saklasaydım iyi olurdu bence. Belki çalışma kapsamı dışında olacaktı ama okulun sonunda zaman kapsülünü açarak çocuklarla değerlendirme yapardık. Onlar içinde farklı bir uygulama olurdu. Zaman kapsülünün uygulanmaması tamamen benim eksikliğimdir. Çocuklarla bireysel görüşmeler ve hafta sonu kurslarında çeşitli etkinlikler yapabilirdim. Belki süreyi uzatmalıydım diye düşüyorum. Çocuklarla bireysel görüşme yapmamın nedeni yeterli zamanın ve uygun bir ortamın olmamasıdır. Hafta sonu kursunda da yaptığım etkinlikleri destekleyebilirdim ama kurslara çok az öğrenci devam ediyordu.

Öğrenemeyecek çocuk olmadığına inanıyorum. Buna daha önce de inanıyordum, bu çalışmayla kendime kanıtlamış olduğuma inanıyorum. Gerekli olan koşullar sağlandığında bu beceri her çocukta geliştirilebilir. Benim öğrencilerim şanssız bir kesim ve bu beceriden, derslerden daha önemli gündemleri var. $\mathrm{Bu}$ nedenle öğrenebildikleri her şey benim için çok anlamlı. Beni sevmelerine çaba sarf ettim ki dersime önem verip benim dediklerimi dinleyerek bu becerilerini geliştirebilsinler. Öğrencilerim çoğu noktada beni kırmadı, derste yaramazlık yaptıklarında üzüldügümü söylediğimde sustular, bazı ödevlerini yapmadılar ama içten bir şekilde buna da kızmadım. Çünkü aile ortamları hakkında, okul dışındaki alışkanlıkları hakkında bilgim var. Okul dışında derslerle ilgilenmelerini beklemiyordum.

$\mathrm{Bu}$ uygulama benim için kesinlikle iyi bir tecrübeydi. Zaten tecrübenin kötüsünün olmadığına inanıyorum. Sınıfımı akademik başarısının düşük olması benim için tecrübemin en önemli boyutu. Böyle bir sınıfta nasıl çalışma yürütülebileceğini gördüm.

$\mathrm{Bu}$ uygulamayla birçok zaman şeridi çizme ve çizdirme, çocuklar için PowerPoint sunusu hazırlama, bilimsel çalışma yapma (özellikle bir problemin çözümü için veri toplama), rol oynama yöntemini uygulama gibi beceriler edindim.

Sosyal bilgiler öğretmeni olarak; bu becerinin geliştirilmesi gereken konularda artık öğrencilere muhakkak zaman şeridi çizdireceğim. Muhakkak insanlık tarihini anlatan zaman şeridini sunacağım. Çünkü öğrenciler bu ikisinde oldukça eksikler ve becerinin en temelinde de bunlar yer alıyor. Bu beceri 4. sınıftan itibaren geliştirilmesi gereken bir beceri ve sosyal bilgilerde sadece benim çalışma yaptığım sınıf seviyesinde ve ünitede yer almıyor. $O$ nedenle oldukça işime yarayacağını düşünüyorum. Farklı sınıf seviyelerinde farklı ünitelerde uygulayabileceğim etkinlikleri öğrendim.

Sosyal bilgiler öğretmeni olarak gerçekten bu becerinin önemli olduğuna inanıyorum. Bu beceri olmadan çocuklar tarihi bilgileri anlamlandıramaz. İnsanın tam anlamlandıramadığı bir şeyi de sevmesi, ilgi duyması beklenemez. Tarihi sevdirebileceğim bu beceriyi geliştirebilmek benim için oldukça önemli. $\mathrm{Bu}$ beceriyi geliştirmek benim için oldukça onure edici olur, çünkü çocuklarda hayatları boyunca kullanabilecekleri bir temel oluşturmuş olacağım. Eğer yüksek lisanstan mezun olabilirsem ilerleyen yıllarda da akademik çalışma yaparsam bu konu üzerine çalışmayı düşünüyorum. Çünkü bu konu hakkında temelim oluştu. Daha güzel ve kapsamlı bir çalışma yapabilirim.

$\mathrm{Bu}$ deneyimi kesinlikle tekrarlamak isterim. Tekrar yapsam elbette aynı olmaz. Öğrencilerle birebir görüşme, zaman kapsülü uygulaması ve hafta sonu kursunda da farklı etkinlikler yapma düşünceleri aklımda kaldı. Aslında hafta sonu kurslarında da yapmak istedim. Ancak çok az öğrenci kursa devam ediyordu. Şuan düşünüyorum da onları kursa çekebilmek için bir fikir üretebilir miydim? Üretseydim bu onları çok zorlamak ve bencilce zorla bir şey yaptırmak mı olurdu? Zaten okula istemeyerek geliyorlar ve sıkılıyorlardı. Bu sorular beni durdurdu ve karar veremedim. Zaman kapsülü uygulamasını yapamamak tamamen benim eksikliğim bunu yaptırabilirdim. Birebir görüşme içinde yer ve zaman sıkıntım vardı. Ancak planlamayı iyi yapabilseydim koşulları zorlasaydım belki bunu da yapabilirdim. Bunda hem benim hem koşulların etkisi var. 
Sonuç olarak, bu uygulamanın, sosyal bilgiler eğitiminde önemli bir beceri olan zaman ve kronolojiyi algılama becerisinin kazandırılmasında yapabileceğim öğretim uygulamalarımı geliştirdiğini söyleyebilirim.

\section{KAYNAKÇA}

Ablak, S. (2017). Sosyal bilgiler programındaki becerilere ilişkin öğrenci algılarının incelenmesi. Doktora tezi, Gazi Üniversitesi Eğitim Bilimleri Enstitüsü, Ankara.

Akbaba, B., Keçe, M. \& Erdem, M. (2012). Sosyal bilgiler dersinde çoklu ortam kullanımının öğrencilerin zaman-kronoloji ve değişim sürekliliği algılama becerilerine etkisi. Sosyal Bilimler Dergisi, 14(2), 237-257.

Aydemir, M. (2015). Ortaokul sosyal bilgiler programında ögrencilere kazandirlması hedeflenen becerilerin kazanım ve ekinlikler ile ögrrenci çalışma kitaplarında yer alma düzeyinin belirlenmesi. Yüksek lisans tezi, Celal Bayar Üniversitesi Sosyal Bilimler Enstitüsü, Manisa.

Aykaç, N. (2007). İlköğretim sosyal bilgiler dersi eğitim-öğretim programına yönelik öğretmen görüşleri. Elektronik Sosyal Bilimler Dergisi, 6(22), 46-73.

Çelikkaya, T. (2011). Sosyal bilgiler programında yer alan becerilerin kazandırılma düzeyi: Öğretmen görüşleri. Kastamonu Eğitim Dergisi, 19(3), 969-990.

Çelikkaya, T. \& Kürümlüoğlu, M. (2017). 2005 Sosyal bilgiler öğretim programında kazandırılması hedeflenen alan becerilerine kitaplarda yer verilme durumu. Mustafa Kemal Üniversitesi Sosyal Bilimler Enstitüsü Dergisi, 14(40), 141-158.

Çelikkaya, T. \& Kürümlüoğlu, M. (2019). Ortaokul öğrencilerinin kronoloji becerilerinin saptanmasına yönelik bir çalışma. Turkish History Education Journal, 8(1), 150-173.

Çelikkaya, T., Yıldırım, T. \& Kürümlüoğlu, M. (2019). Öğrenciler ve sosyal bilgiler öğretmenlerinin programdaki becerilere ilişkin beceri hiyerarşileri, gerekçeleri ve önerileri. MANAS Sosyal Araştırmalar Dergisi, 8(1), 111-132.

Çiviler, M. (2019). Ortaokul 7. sinıf sosyal bilgiler dersinde öğrencilerin tarihsel düşünme becerilerini geliştirme: Bir eylem araştırması. Yüksek lisans tezi, Marmara Üniversitesi Eğitim Bilimleri Enstitüsü, İstanbul.

Demircioğlu, İ. H. (2005). Sekizinci sınıf öğrencilerinin tarih öğretiminde kullanılan zaman ve kronolojiyle ilgili bazı kavramları anlama düzeyleri. Eurasian Journal of Educational Research, (19), 155-163.

Demircioğlu, İ. H. (2005). Sekizinci sınıf öğrencilerinin tarih öğretiminde kullanılan zaman ve kronolojiyle ilgili bazı kavramları anlama düzeyleri. Eurasian Journal of Educational Research, (19), 155-163.

Demircioğlu, İ. H. \& Akengin, H. (2012). Zaman ve mekâna ilişkin becerilerin öğretimi. C. Öztürk (Ed.), Sosyal bilgiler öğretimi: Demokratik vatandaşllk eğitimi (ss. 187-224). Ankara: Pegem Akademi.

Dündar, Ş. (2008). İlköğretim sosyal bilgiler dersi ögrrenme ortamlarının yapılandırmacı özellikler açısından değerlendirilmesi. Doktora tezi, Marmara Üniversitesi Eğitim Bilimleri Enstitüsü, İstanbul.

Erdem, M. (2017). 6-7. sinff sosyal bilgiler programinda bulunan alana özgü becerilerin etkinlikler yoluyla kazandırılması. Yayımlanmamış Doktora tezi, Gazi Üniversitesi Eğitim Bilimleri Enstitüsü, Ankara.

Filoğlu, S. (2018). 2005 Sosyal bilgiler programındaki alan becerilerinin öğrencilerin öznel algılarına göre kazanılma durumları. Yüksek lisans tezi, Ahi Evran Üniversitesi Sosyal Bilimler Enstitüsü, Kırşehir.

Güngör Akıncı, B. \& Dilek, D. (2012). Sosyal bilgiler öğretiminde temsili resim kullanımıyla tarihsel düşünme becerilerinin geliştirilmesi. Marmara Üniversitesi Atatürk Eğitim Fakültesi Eğitim Bilimleri Dergisi, 36(36), 5-27.

Johnson, A. P. (2015). Eylem araştırması el kitabı. (Y. Uzuner ve M. Özten Anay, Çev. Ed.) Ankara: Anı

Kabapınar, Y. (2014). Kuramdan uygulamaya sosyal bilgiler öğretimi (4.Bask1). Ankara: Pegem A.

Kekeç, M. (2018). Zaman ve kronoloji becerisinin kazandırlmasında modelleme tekniğinin kullanilmast. Yüksek lisans tezi, Karadeniz Teknik Üniversitesi Eğitim Bilimleri Enstitüsü, Trabzon.

Kıbıcı, N. (2019). Sosyal bilgiler öğretmenlerinin, velilerin ve öğrencilerin sosyal bilgiler dersi becerilerine iliş̧kin önem sıraları. Yüksek lisans tezi, Uşak Üniversitesi Sosyal Bilimler Enstitüsü, Uşak.

Milli Eğitim Bakanlığı. (2005). İlköğretim sosyal bilgiler dersi 6-7. sinıflar öğretim programı ve kılavuzu (taslak basim). Ankara: MEB.

Mutluer, C. (2013). Sosyal bilgiler programlarında yer alan beceriler hakkında sosyal bilgiler öğretmen görüşleri (İzmir Menemen örneği). Turkish Studies, 8(7), 355-362.

Öztürk, C. (2006). Sosyal bilgiler: Toplumsal yaşama disiplinlerarası bir bakış. C. Öztürk (Ed.), Hayat bilgisi ve sosyal bilgiler öğretimi yapılandırmacı bir yaklaşım (ss. 18-21). Ankara: Pegem Yayıncılık.

Safran, M. \& Şimşek, A. (2006). İlköğretim öğrencilerinde tarihsel zaman kavramının gelişimi. İlköğretim Online, 5(2), 87-109.

Sağlam, H. İ., Tınmaz, E. \& Hayal, M. A. (2015). Sınıf öğretmenlerinin "zaman ve kronolojiyi algılama" becerisini öğretme deneyimlerine fenomonolojik bir bakış. Turkish History Education Journal, 4(1), 49-66.

Senemoğlu, N. (2013). Gelişim, öğrenme ve öğretim kuramdan uygulamaya. (23.Baskı). Ankara: Yargı. 
Şimşek, A. (2007). İlköğretim 5. sınıf öğrencilerinin kronolojik algılarının geliştirilmesine yönelik yarı deneysel bir çalışma. Kuram ve Uygulamada Eğitim Bilimleri, 7(1), 589-615.

Taşkıran, C., Baş, K. \& Bulut, B. (2016). Sosyal bilgiler dersinin kendine özgü becerilerinin kazandırılma düzeyi. Sosyal Bilimler Dergisi, 6(11), 1-19.

Üztemur, S. (2017). Sosyal bilgiler öğretimi bağlamında tarihi mekânlar ve müze ile eğitim etkinliklerinin geliştirilmesi ve uygulanması: Manisa ili örneğinde bir eylem araştırması. Doktora tezi, Uşak Üniversitesi Sosyal Bilimler Enstitüsü, Uşak.

Üztemur, S., Dinç, E. \& Acun, İ. (2018). Müzeler ve tarihi mekânlarda uygulanan etkinlikler aracıllğıyla öğrencilerin sosyal bilgilere özgü becerilerinin geliştirilmesi. Mehmet Akif Ersoy Üniversitesi Eğitim Fakültesi Dergisi, (46), 294-324. 


\section{EXTENDED SUMMARY}

\section{INTRODUCTION}

Social studies is one of the courses offered in primary education that integrated with the concepts of knowledge-skills-values, and in which social sciences are taught by being simplified (Kabapınar, 2014). According to Öztürk (2006), social studies course contributes to the socialization of the individuals, enables them to learn about their past, make sense of the present and prepare them for future. In addition, social studies course has a key role in the development of the personality of the individual and in raising productive individuals who are compatible with the society (Aykaç, 2007). Moreover, social studies course is generally defined as a course that is integrated around knowledge, skills and values with the aim of enabling individuals to get to know themselves, their near and distant environment (Dündar, 2008).

The ability to perceive time and chronology is a skill specific to the social studies course (Ministry of National Education, [MoNE], 2005). In order to teach the subjects of the Social Studies course effectively, students must acquire this skill (Demircioğlu \& Akengin, 2012). When the literature is examined, it is seen that many studies have been conducted on the ability to perceive time and chronology (Ablak, 2017; Akbaba, Keçe \& Erdem, 2012; Aydemir, 2015; Çelikkaya, 2011; Çelikkaya and Kürümlüoğlu, 2017; Çelikkaya and Kürümlüoğlu, 2019; Çelikkaya, Yıldırım and Kürümlüoğlu , 2019; Çiviler, 2019; Demircioğlu, 2005; Erdem, 2017; Filoğlu, 2018; Güngör Akınc1 \& Dilek, 2012; Kekeç, 2018; Kıbıc1, 2019; Mutluer, 2013; Safran and Şimşek, 2006; Sağlam, Tınmaz and Hayal, 2015; Şimşek, 2007; Taşkıran, Baş and Bulut, 2016; Üztemur, 2017; Üztemur, Dinç, \& Acun, 2018). When these studies are examined, it is concluded that the ability to perceive time and chronology cannot be sufficiently developed in students and that various materials and activities other than the textbook should be used to improve it.

The main purpose of this study was to examine whether the practices of various activities and the use of multimedia in the classroom were effective in the development of students' perception of time and chronology, and to define the effective practices. In line with this main purpose, in this study, the question of; "What happened in the practices conducted to improve the students' perception of time and chronology in the seventh-grade social studies course, and how did the plan work?" was sought to be answered.

\section{METHOD}

\section{Research Design}

An action research was employed to answer the question of the study. Action research is a systematic and orderly way for teachers to observe and examine their own practices. Action research aims to improve teacher's teaching practices (Johnson, 2015).

\section{Study Group}

The study group consisted of 21 seventh grade students who were studying at one of the classes taught by the first author of this study, who is a social studies course teacher. Of these students, 10 were male and 11 were female.

\section{Data Collection Tools}

Data in the study were collected through the achievement test and research diary. The achievement test was developed by Kekeç (2018). Observations, feelings, thoughts and student comments related to the process in the study were recorded in the research diary.

\section{Data Collection}

The achievement test was applied twice at the beginning and end of the application. The research diary is written after the lesson or at the end of the day. A diary of thirty six pages was obtained.

\section{Data Analysis}


Descriptive statistics of the scores obtained from the pre-and post-test achievement tests were calculated, and the mean scores of the two tests were analyzed by dependent groups t-test. In the analysis of the data obtained from the research diary, "inductive analysis" was employed.

\section{FINDINGS}

The pre-test mean score of the students was calculated as 9.48 and the post-test mean score was calculated as 13.38. There was a significant difference between the mean scores in favor of the post-test $(\mathrm{t}(20)=-3.069$, $\mathrm{p}<0.05)$. Accordingly, it can be said that the practices has made a significant difference in the post-test scores compared to the pre-test scores. As a result of the inductive analysis, it was concluded that the time strip was an effective tool, role playing was an effective method, and the practices implemented generally worked.

\section{DISCUSSION AND CONCLUSION}

The main findings obtained in the study are as follows: A significant difference was found between the pretest mean score and the post-test mean score in favor of the post-test. It can be said that the practices of various activities and the use of multimedia in the classroom are effective in the development of students' ability to perceive time and chronology. The teacher made some decisions during the application process. These decisions are as; "Students should be provided with more time strip examples, and they should be encouraged to draw more time strips.", "Firstly, timelines that are linear, and metric should be used.", "Synchronous time strip is not effective.", "Virtual museum visits did not attract students' attention and interest", "Videos were effective. " In this case, it can be argued that time strip is an effective tool in gaining students the ability to perceive time and chronology. Time strip has been the most frequently used material to gain the ability to perceive time and chronology. It is seen that students made progress in drawing timelines, making accurate temporal sequencing, and interpreting the timeline when compared to their initial status. Students understood the concepts of age, century, change, continuity, proximity-distance, before and after Christ, and quarter. However, there were some students could not achieve this progress. It was also obtained that that role playing method was effective in enabling students gain the ability to perceive time and chronology.

There were also students who could not draw a timeline, could not perform temporal sequencing in the timeline, could not distinguish the ages and could not know the age they lived in. This situation can be explained by the deficiencies in students' cognitive enrty behaviors. Cognitive entry behaviors are essential qualities required for all kinds of learning and are considered as the most important factor that influence student achievement in schools. However, cognitive entry behaviors are characteristics resistant to change (Senemoğlu, 2013, p. 446-447).

As a result, it can be said that the practicec of various activities and the use of multimedia in the classroom are generally effective in developing students' ability to perceive time and chronology, time strip is an effective material, and role playing is an effective method.

And Mathematics Performance İn Associate Degree Nursing Students. Nurs Educ Perspect, 29(4), 226-229 